\title{
Spatio-temporal genetic structure and gene flow between two distinct shell morphs of the planktonic developing periwinkle Littorina striata (Mollusca: Prosobranchia)
}

\author{
Hans De Wolf ${ }^{1, *}$, Thierry Backeljau ${ }^{2}$, Ron Verhagen ${ }^{1}$ \\ ${ }^{1}$ Evolutionary Biology Group, University of Antwerp (RUCA), Groenenborgerlaan 171, B-2020 Antwerp, Belgium \\ ${ }^{2}$ Royal Belgian Institute of Natural Sciences (KBIN), Vautierstraat 29, B-1000 Brussels, Belgium
}

\begin{abstract}
The planktonic developing periwinkle Littorina striata produces both nodulose and smooth shells, which were originally regarded as 2 separate species. Although both morphs occur microsympatrically, their distribution is not random. Nodulose shells predominate at wave-sheltered sites, whereas smooth shells are more common at wave-exposed sites. The degree of genetic similarity between the 2 shell types and their microgeographic spatio-temporal genetic structuring were investigated using allozyme electrophoresis. This indicated that: (1) both morphs share a common gene pool, (2) gene flow between populations is high and of comparable magnitude to gene flow between both morphs, (3) the population genetic structure of L. striata remains stable over a sampling period of 3 yr, and (4) genetic and morphological distances between populations are not correlated. These results thus confirm the conspecific status of the 2 shell types and suggest that shell variability and spatial patterning in L. striata persist in the presence of intense gene flow.
\end{abstract}

KEY WORDS: Littorina striata $\cdot$ Planktonic development $\cdot$ Gene flow $\cdot$ Spatio-temporal variation $\cdot$ Shell morphology $\cdot$ Allozymes

\section{INTRODUCTION}

Many intertidal prosobranchs have shells that are highly polymorphic with respect to colour, size, shape and sculpture (e.g. Struhsaker 1968, Crothers 1981, 1992, Boulding \& Van Alstyne 1993, Chapman 1994, Johannesson 1996, Hull et al. 1996, McQuaid 1996, Reid 1996). Although most of this variability can be explained in functional terms (e.g. Crothers 1981, Seeley 1986, McQuaid 1996, Reid 1996), it often remains unclear whether shell polymorphisms are maintained and patterned by natural selection or ecophenotypic plasticity. Current theories usually invoke natural selection to explain shell variation and its patterning in non-planktonic developers (e.g. Seeley 1986, Chapman 1994, Johannesson \& Johannesson 1996), as non-planktonic de-

•E-mail: dewolf@ruca.ua.ac.be veloping prosobranchs have limited dispersal abilities and are therefore subjected to greater genetic population differentiation (e.g. Scheltema 1971, Crisp 1978), as seen for instance in the non-planktonic developing littorinids Littorina saxatilis (Johannesson et al. 1993, Rolán-Alvarez et al. 1996, Johannesson \& Tatarenkov 1997) and L. mariae (Tatarenkov \& Johannesson 1994). There is, however, growing evidence that prosobranchs with high dispersal abilities (i.e. with planktonic development) may also be genetically more subdivided than is currently assumed (e.g. Palumbi 1994 and references therein). Moreover, some planktonic developers display a considerable amount of shell variability too (e.g. Stiven 1992, Karakousis et al. 1993, Frid \& Fordham 1994, Reid 1996 and references therein, Reimer \& Tendengren 1996).

The periwinkle Littorina striata King \& Broderip, 1832 , is one such polymorphic planktonic developing 
prosobranch (Rosewater 1981, Reid 1996, De Wolf et al. 1997). The species produces 2 major shell morphotypes: one with a spirally sculptured, nodulose shell, the other having a nearly smooth shell without nodules (e.g. Rosewater 1981, Reid 1996, De Wolf et al. 1997). Recent attempts to describe and interpret the microscale patterning and functionality of this polymorphism (Britton 1995, Vedel \& Depledge 1995, De Wolf et al. 1997) suggested that at least part of the shell variability shows ecological correlates (Britton 1995, De Wolf et al. 1997). Earlier authors even went so far as to suggest that both morphotypes represent different species (e.g. Dunker 1853, Weinkauff 1882). Although it is now generally accepted that only 1 species is involved (e.g. Reid 1996), it is still unclear whether and to what extent the 2 morphotypes are genetically similar. This is equivalent to asking whether both morphotypes share a common gene pool. If so, it remains to be investigated how they maintain their morphological integrity, differentiation and ecological patterning (De Wolf et al. 1997).

As a first step in the resolution of these issues we applied allozyme electrophoresis to estimate the degree of gene flow and spatio-temporal genetic differentiation among populations and morphotypes of Littorina striata at a microgeographic scale. To this end we used the locations and material that were analyzed for morphometric variation by De Wolf et al. (1997).

\section{MATERIAL AND METHODS}

Littorina striata. L. striata is an endemic periwinkle in the Macaronesian archipelagos (Azores, Madeira, Canary Islands and Cape Verde Islands), where it is common in the upper littoral and the littoral fringe of rocky shores (Rosewater 1981, Reid 1996). At Ilheu de Vila Franca do Campo (hereafter referred to as Ilheu), a drowned volcanic crater situated $1 \mathrm{~km}$ off the south coast of the island of São Miguel (Azores), the 2 morphotypes of $L$. striata co-occur microsympatrically, even though they are not randomly distributed (Britton 1995, De Wolf et al. 1997). The nodulose morph, which is on average smaller and lighter than the smooth morph, is mainly found at the sheltered lagoon inside of the crater, whereas the larger and heavier smooth morph dominates the crater's wave-exposed outside (De Wolf et al. 1997). Regardless of the morphotype, shells from the lagoon are on average smaller, less globose and have a smaller aperture compared to shells from the wave-exposed outside. In addition, both morphs enlarge their aperture size within a few months when transplanted from the lagoon to the outside (De Wolf et al. 1997). Yet, within a wave exposure regime, the smooth morph has on average a larger aperture (De Wolf et al. 1997).
Allozyme electrophoresis. Littorina striata ( $\mathrm{n}=$ 1078) was collected annually (August 1992, July 1993 and July 1994) at 8 sites in Ilheu, yielding a total of 24 samples (i.e. 3 consecutive samples per site). Four sites were situated in the sheltered lagoon inside the crater (1 to 4 ), while the 4 other sites were located at the wave-exposed outside of the crater (5 to 8). Two outside locations were low-shore populations (5 and 7), the 2 others were high-shore populations ( 6 and 8 ). For a description of the area and sampling sites, see Morton (1990) and De Wolf et al. (1997).

Specimens were starved for $4 \mathrm{~d}$ and subsequently frozen and stored at $-80^{\circ} \mathrm{C}$. Each individual was morphologically characterized by De Wolf et al. (1997). Soft body parts were prepared for vertical polyacrylamide gel electrophoresis (PAGE) as described by Backeljau \& Warmoes (1992). A preliminary screening of 38 enzymes yielded 4 well-resolved, polymorphic loci that could be used for population genetic analysis: glucose phosphate isomerase (GPI, E.C. 5.3.1.9), 6phosphogluconate dehydrogenase (PGD, E.C. 1.1.1.44) and malate dehydrogenase (MDH, E.C. 1.1.1.37) were resolved in a Tris/citric acid buffer at $\mathrm{pH} 8.0$, while mannose phosphate isomerase (MPI, E.C. 5.3.1.8) was analyzed using a Tris/glycine electrode buffer and a Tris/HCl gel buffer, both at pH 9.0. Enzyme stainings were adapted from Harris \& Hopkinson (1976).

Statistical analysis. Genotype frequency departures from Hardy-Weinberg (HW) equilibrium conditions were tested with chi-squared and exact probability tests. Chi-squared tests were performed using the CHIHW program (v. 3.1) of Zaykin \& Pudovkin (1993), which applies a pseudo-probability test based on the Monte Carlo procedure (1000 permutations) proposed by Roff \& Bentzen (1989). Exact probabilities were estimated with the GENEPOP software package v. 1.1 (Raymond \& Rousset 1995), which applies the Markov chain method proposed by Guo \& Thompson (1992).

For each population, linkage disequilibria were tested for all pairwise loci comparisons, using the GENEPOP software package v. 1.1 (Raymond \& Rousset 1995).

As several mollusc species show a relationship between individual heterozygosity and size (e.g. Koehn \& Gaffney 1984, Gaffney et al. 1990, Zouros \& Pogson 1994), we tested this possibility in L. striata too, because it could affect our population genetic analysis, given the differential size and morphotype distribution of Littorina striata at Ilheu. Therefore, for each sampling year we calculated and tested Spearman Rank correlations between individual heterozygosity (the number of allozyme loci at which a specimen is heterozygous, i.e. 0 to 4) and individual values for shell height, shell width, aperture height, aperture width, height of the shell top, total weight and body weight. 
These calculations were performed using the STATISTICA v. 5.0 software (Statsoft, Tulsa, OK, USA).

Allele frequency heterogeneities between populations and morphotypes were tested per sampling year with $\mathrm{R} \times \mathrm{C}$ contingency tables. The heterogeneity between morphotypes was assessed for the lagoon and outside specimens separately, in order to reduce possible spatial/ecological differentiation between the sampling areas. In addition, temporal allele frequency heterogeneities were tested within each population, among all 3 sampling years. All these analyses were performed with the GENEPOP v. 1.1 (Raymond \& Rousset 1995) package, which applies a Markov chain method (Guo \& Thompson 1992) to obtain unbiased estimates of the Fisher exact test statistics.

The degree of genetic differentiation between populations was estimated per sampling year by means of Wright's (1965) $F$ and Nei's (1973, 1977) G statistic as implemented by the programs BIOSYS (Swofford \& Selander 1989) and GENESTAT v. 3.31 (Lewis 1992). Because $F_{S T} / G_{S T}$ values were not significantly different from 0 , the amount of gene flow $(\mathrm{Nm})$ between populations was only inferred from private allele frequencies, i.e. the frequencies of alleles that are unique to 1 population only (Slatkin 1985a, Slatkin \& Barton 1989). These latter were calculated with the program GENESTAT v. 3.31 (Lewis 1992).

Finally, per sampling year, Prevosti distance (Wright 1978) was calculated between populations using the program BIOSYS (Swofford \& Selander 1989). The relationship between these distances and the squared Mahalanobis distances among the same populations, calculated from the morphological data of De Wolf et al. (1997), was evaluated with a Mantel test, using 1000 permutations, implemented by the NTSYS v. 1.80 program (Rohlf 1993). The distance matrices are available upon request.

A significance level of $5 \%$ was used throughout. The sequential Bonferroni technique was employed to correct for false assignments of significance by chance alone (multiple testing problem) (Rice 1989).

\section{RESULTS}

Allele frequencies and the results of the HW tests are provided in Appendix 1, which shows that over the $3 \mathrm{yr}$, and irrespective of the test statistic used, only 3 cases of HW deviations were observed.
After sequential Bonferroni correction for multiple testing, none of the 3 deviations remained significant No linkage disequilibria were detected (available upon request).

With the exception of 1 case (body weight in 1993), no significant Spearman Rank correlations were found between individual heterozygosities and size/weight variables (Table 1). However, this particular correlation was, here too, no longer significant after Bonferroni correction. Hence, mere size related heterozygosity differences were not expected to affect our analyses.

Table 2 shows the results of the analysis of allele frequency heterogeneities between both morphotypes, within the lagoon and outside of the crater, in order to correct for possible genetic heterogeneity due to wave exposure differences. After sequential Bonferroni correction, no significant genetic heterogeneity was detected between the morphotypes (Table 2). Table 3 shows the results of the analysis of allele frequency heterogeneities between populations (i.e. mixture of both morphotypes) per sampling year. Out of 300 tests, only 21 were significant. However, after sequential Bonferroni correction, none of these tests remained significant. Likewise, no significant genetic heterogeneity was detected between the sampling years, after sequential Bonferroni correction (Table 4).

Table 1. Littorina striata. Spearman Rank correlations between individual heterozygosity and morphometric characteristics (HS= shell height; WS = shell width $\mathrm{HA}=$ aperture height, WA = aperture width; $H T=$ shell top height $; W=$ total weight; $B W=$ body weight)

\begin{tabular}{|lccccrr|}
\hline Variable & \multicolumn{2}{c}{${ }^{1992}$} & \multicolumn{2}{c}{1993} & \multicolumn{2}{c|}{1994} \\
& $\mathrm{R}^{2}$ & $\mathrm{p}$ & $\mathrm{R}$ & $\mathrm{p}$ & $\mathrm{R}$ & $\mathrm{p}$ \\
\hline HS & -0.1135 & 0.1835 & 0.1547 & 0.0973 & 0.0022 & 0.9802 \\
WS & -0.1291 & 0.1298 & 0.1644 & 0.0778 & -0.0747 & 0.3984 \\
HA & -0.0918 & 0.2822 & 0.1650 & 0.0775 & -0.0465 & 0.5997 \\
WA & -0.0067 & 0.4353 & 0.1722 & 0.0645 & -0.0351 & 0.6916 \\
HT & -0.0964 & 0.2588 & 0.1400 & 0.1350 & -0.0048 & 0.9571 \\
TW & -0.0761 & 0.3735 & 0.1547 & 0.0972 & -0.0365 & 0.6806 \\
BW & -0.0950 & 0.2661 & 0.2003 & 0.0311 & -0.0223 & 0.8013 \\
\hline
\end{tabular}

Table 2. Littorina striata. Genetic heterogeneity analysis. Probabilities of exact tests for comparison of smooth and nodulose morphotypes, within the lagoon and outside

\begin{tabular}{|lcccccc|}
\hline \multirow{2}{*}{ Locus } & \multicolumn{2}{c}{1992} & \multicolumn{2}{c}{1993} & \multicolumn{2}{c|}{1994} \\
& Lagoon & Outside & Lagoon & Outside & Lagoon & Outside \\
\hline GPI & 0.8311 & 0.8056 & 0.4513 & 0.8899 & 0.9384 & 0.4888 \\
MPI & 0.1168 & 0.0772 & 0.6755 & 0.3956 & 0.8974 & 0.3297 \\
PGD & 0.3262 & 0.6979 & 0.0421 & 0.0051 & 0.3679 & 0.0758 \\
MDH & 1.0000 & 1.0000 & 0.3552 & 0.2576 & 0.3988 & 1.0000 \\
& & & & & & \\
\hline
\end{tabular}


Table 3. Littorina striata. Analysis of allele frequency heterogeneity tests between populations, using exact probabilities for pairwise sampling site comparisons. Out of a possible 300 tests, only those are shown where at least 1 significant heterogeneity was scored. na = test statistic non-applicable, due to monomorphicity of the considered locus

\begin{tabular}{|c|c|c|c|c|c|c|c|c|c|}
\hline \multicolumn{2}{|l|}{ Population } & \multicolumn{2}{|l|}{1992} & \multicolumn{3}{|c|}{1993} & \multicolumn{3}{|c|}{1994} \\
\hline Locus: & GPI & MPI & PGD & GPI & MPI & PGD & GPI & MPI & PGD \\
\hline $1-4$ & 0.7681 & 0.7052 & 0.5719 & 0.2410 & 0.1547 & na & 0.0239 & 0.2345 & 0.2552 \\
\hline $1-5$ & 0.9185 & 0.0346 & 0.2761 & 0.4265 & 0.7351 & 0.4936 & 0.1826 & 1.0000 & 1.0000 \\
\hline $1-8$ & 0.7567 & 0.0602 & 1.0000 & 0.1614 & 0.1204 & 0.0255 & 0.1510 & 1.0000 & 1.0000 \\
\hline $2-4$ & 0.2210 & 0.6367 & 0.3309 & 0.0205 & 0.7970 & 0.2600 & 0.3037 & 0.0948 & 0.4537 \\
\hline $2-5$ & 0.3682 & 0.0019 & 0.4558 & 0.6044 & 0.1343 & 0.3645 & 0.8926 & 0.5667 & 0.1607 \\
\hline $2-6$ & 0.1928 & 0.0052 & 0.1957 & 0.9882 & 1.0000 & 0.3561 & 0.7124 & 0.6567 & 1.0000 \\
\hline $2-8$ & 0.8900 & 0.0023 & 0.9138 & 1.0000 & 0.8112 & 0.4881 & 0.6590 & 0.6645 & 0.0786 \\
\hline $3-4$ & 0.7679 & 0.0415 & 0.5902 & 0.1074 & 0.1386 & na & 0.2504 & 0.5366 & 0.2449 \\
\hline $3-7$ & 0.9557 & 0.5934 & 1.0000 & 0.1171 & 0.3937 & 0.0493 & 0.6517 & 0.3966 & 0.6359 \\
\hline $3-8$ & 0.7074 & 0.6997 & 0.8314 & 0.2086 & 0.1135 & 0.0107 & 0.7132 & 0.8003 & 1.0000 \\
\hline $4-5$ & 0.4500 & 0.0010 & 0.0341 & 0.0213 & 0.1111 & 0.5087 & 0.3347 & 0.2476 & 0.2513 \\
\hline $4-6$ & 0.1047 & 0.0110 & 0.0177 & 0.0740 & 1.0000 & 1.0000 & 0.0231 & 0.1106 & 0.4868 \\
\hline $4-7$ & 0.5600 & 0.3059 & 1.0000 & 0.0367 & 0.7956 & 0.1360 & 0.1380 & 1.0000 & 0.2320 \\
\hline $4-8$ & 0.4903 & 0.0102 & 0.4737 & 0.0344 & 1.0000 & 0.0434 & 0.5217 & 0.1654 & 0.0929 \\
\hline $5-6$ & 0.0333 & 0.8256 & 1.0000 & 0.4869 & 0.1389 & 0.4907 & 0.1581 & 0.8078 & 0.1095 \\
\hline
\end{tabular}

Table 4. Littorina striata. Analysis of allele frequency heterogeneity tests within each population, among all 3 sampling years. na $=$ test statistic non-applicable, due to monomorphicity of the considered locus

\begin{tabular}{|lcccc|}
\hline Site & GPI & MPI & PGD & MDH \\
\hline 1 & 0.7093 & 0.3006 & 0.0956 & na \\
2 & 0.6562 & 0.0049 & 0.9078 & 0.2880 \\
3 & 0.5723 & 0.5239 & 0.0576 & na \\
4 & 0.8312 & 0.0546 & 0.4433 & 0.58968 \\
5 & 0.0540 & 0.1053 & 0.0395 & 0.30456 \\
6 & 0.8165 & 1.0000 & 0.1477 & na \\
7 & 0.3142 & 0.5205 & 0.0393 & na \\
8 & 0.3812 & 0.9340 & 0.0295 & 0.8140 \\
\hline
\end{tabular}

The overall mean $F_{\mathrm{ST}}\left(G_{\mathrm{ST}}\right)$ values were small and not significantly different from 0 , suggesting little or no population differentiation (Table 5). Hence, private allele based $\mathrm{Nm}$ estimates were high (i.e. $\mathrm{Nm} \gg$ 1) (Table 6), though fluctuated depending on the gene flow calculation method used (i.e. Slatkin 1985a or Slatkin \& Barton 1989 ), or the sampling year that was considered (Table 6).

The Mantel tests of the matrix correlation between the Prevosti and squared Mahalanobis distances per sampling year revealed no significant relationships (Table 7). Hence, genetic and morphometric data were apparently not correlated.

\section{DISCUSSION}

The low mean $F_{\mathrm{ST}}\left(G_{\mathrm{ST}}\right)$ values reported here for Littorina striata are comparable to corresponding values observed in other prosobranchs with planktonic development (e.g. Maestro et al. 1982, Kartavtsev \& Zaslavskaya 1983, Janson 1985a, b, Brown 1991, Johannesson 1992, Macaranas et al. 1992, Ford \& Mitton 1993, Karakousis et al. 1993, Parsons \& Ward 1994, Dayan \& Dillon 1995, Benzie \& Williams 1996), whereas they are considerably lower than $F_{\mathrm{ST}}\left(G_{\mathrm{ST}}\right)$ values of non-planktonic developing species (e.g. Knight et al. 1987, Grant \& Utter 1988, Johannesson \& Johannesson 1990, Ward 1990, Rolan-Alvarez et al. 1995, Johnson \& Black 1996). Moreover, the genetic population structure of $L$. striata appears temporally stable, as no temporal effects could be detected in the genetic heterogeneity

Table 5. Littorina striata. Summary of $F_{\mathrm{ST}}$ statistic (Wright 1965) and $G_{\mathrm{ST}}$ statistic (Nei 1973,1974) at all loci [significance of $F_{\mathrm{ST}}$ was tested by means of the Pearson chi-squared statistic for an $M \times N$ contingency table with $(M-1)(N-1)$ degrees of freedom where $M=$ number of populations and $\mathrm{N}=$ number of alleles]

\begin{tabular}{lccccccc|}
\hline \multirow{2}{*}{ Locus } & \multicolumn{2}{c}{${ }^{1992}$} & \multicolumn{2}{c}{1993} & \multicolumn{2}{c}{1994} \\
& $F_{\text {ST }}$ & $G_{\mathrm{ST}}$ & $F_{\mathrm{ST}}$ & $G_{\mathrm{ST}}$ & $F_{\mathrm{ST}}$ & $G_{\mathrm{ST}}$ \\
\hline GPI & 0.010 & 0.000 & 0.023 & 0.011 & 0.015 & 0.003 \\
MPI & 0.032 & 0.022 & 0.015 & 0.002 & 0.010 & 0.000 \\
PGD & 0.016 & 0.006 & 0.031 & 0.017 & 0.009 & 0.000 \\
MDH & 0.011 & 0.002 & 0.010 & 0.000 & 0.016 & 0.005 \\
Mean & 0.015 & 0.005 & 0.022 & 0.009 & 0.013 & 0.001 \\
\hline
\end{tabular}


Table 6. Littorina striata. Gene flow estimates based on private alleles, for 1992, 1993, 1994 and for all 3 sampling years. $P(1)$ : frequency of private alleles; $N_{\text {sam }}$ : sample size

\begin{tabular}{|lrrrc|}
\hline & 1992 & 1993 & 1994 & Overall \\
\hline $\mathrm{P}(1)$ & 0.0085 & 0.0290 & 0.0135 & 0.014 \\
$\mathrm{~N}_{\text {sam }}$ & 50.1875 & 35.4338 & 38.5625 & 41.3646 \\
$\mathrm{Nm}$ & 50.0186 & 6.2359 & 26.0442 & 22.5928 \\
(Slatkin 1985a) & & & & \\
Nm & 26.6414 & 5.0466 & 16.2412 & 14.2647 \\
(Slatkin \& Barton 1989) & & & \\
\hline
\end{tabular}

Table 7. Littorina striata. Mantel test for correlation between Prevosti genetic and squared Mahalanobis distances

\begin{tabular}{|lcc|}
\hline Sampling year & Matrix correlation & $\mathrm{p}$ \\
\hline 1992 & 0.1161 & 0.6750 \\
1993 & 0.1172 & 0.7167 \\
1994 & 0.1516 & 0.7587 \\
\hline
\end{tabular}

analysis and as annual $F_{\mathrm{ST}}\left(G_{\mathrm{ST}}\right)$ values were highly similar. Depending on which gene flow calculation method is used (i.e. Slatkin 1985a vs Slatkin \& Barton 1989), different $\mathrm{Nm}$ estimates can be obtained (De Wolf et al. 1995), though in this study, with all Nm values well over 1 , we conclude that they are of comparably high magnitude. Hence, gene flow estimates are high and comparable among the 3 sampling years. With Nm values well over 1 it is expected that population differentiation due to random genetic drift should not occur (e.g. Slatkin 1985b). Similarly, there is no genetic differentiation between the 2 morphotypes, which supports their conspecific status. Hence, the shell polymorphism in L. striata and its microscale spatial/ecological patterning seem to persist in the presence of a substantial amount of gene flow, which counteracts genetic population differentiation at the 4 loci investigated.

The ecological patterning of the 2 morphotypes in Littorina striata (i.e. nodulose shells are more abundant at wave-sheltered sites, while smooth shells dominate at wave-exposed shores) seems at first sight comparable to the distribution of 2 shell morphotypes in the non-planktonic developing periwinkle L. saxatilis along the Galician coast (Spain) (Johannesson et al. 1995, Rolán-Alvarez et al. 1996). There, it appears that upper, less wave-exposed shore levels are occupied by ridged shells, while the lower, heavily wave-exposed shore levels are dominated by smooth shells (RolánAlvarez et al. 1996). In mid-shore zones where both morphs occur together and may produce 'hybrid' shells, there is behavioural evidence for non-random mating (Johannesson et al. 1995, Rolán-Alvarez et al. 1995). In addition, allozyme analyses have shown that for a given shore, gene flow between shell forms is lower compared to gene flow within each morphotype, even though there seems to be no significant genetic differentiation between the 2 morphs (Johannesson et al. 1993, Rolán-Alvarez et al. 1996). Furthermore it has been shown in Swedish populations of L. saxatilis that genetic differentiation is not only caused by limited gene flow but can also result from specific habitat related effects (Johannesson \& Tatarenkov 1997). The situation of the Galician L. saxatilis morphotypes has been interpreted as indicating partial reproductive isolation, which may represent a possible case of incipient sympatric speciation (Johannesson et al. 1995).

Despite the similarity between the morphological patterning in Littorina striata and Galician L. Saxatilis, our data suggest that the 2 morphotypes in L. striata are not reproductively isolated and therefore it is unlikely that they would represent another case of incipient sympatric speciation. Yet, we have no behavioural data on the possibility of non-random mating. Given the fundamentally different developmental modes between L. striata (planktonic larvae) and Galician L. saxatilis (brooder releasing crawling juveniles), one might wonder whether the mechanisms that are responsible for the comparable microscale morphological patterning in both species are similar too.

Rolán-Alvarez et al. (1996) suggested that selection maintains the differential microenvironmental distribution of the smooth and ridged shells in Littorina saxatilis. In L. striata, in contrast, it is much less clear whether, and to what extent, selection determines morphological patterning. This issue is more complicated in L. striata, as selection and/or plasticity may act before, during or after settlement of the larvae, a problem not encountered in $L$. saxatilis, whose offspring immediately crawl around in the neighbourhood of the adults.

A transplantation experiment executed at the same sites where the present material was sampled suggested that some aspects of shell morphology (i.e. aperture size) of Littorina striata may be plastic (i.e. ecophenotypic). There is, however, no clear evidence of nodulose shells becoming smooth or vice versa during lifetime (Reid 1996), so that shell sculpture in $L$. striata seems to be fixed. De Wolf et al. (1997) discussed the possible functional significance of several shell features in L. striata at llheu, but such considerations are not sufficient to decide about underlying mechanisms.

In Littorina picta (now Nodilittorina hawaiiensis), another planktonic developing littorinid with sculptural variation, nodulation is maintained by selection (Struhsaker 1968). In contrast, our findings reveal a 
spatio-temporal homogeneity of allelic frequencies and thus an abscence of genetic differentiation between both morphs of $L$. striata. If selection, rather than plasticity is responsible for the observed morphological heterogeneity and patterning in in this species, as is supposed to be the case in L. saxatilis and in L. picta, then it should be very intense in order to overcome the homogenizing effects of high gene flow which seem to exist between both morphs.
Obviously, further genetic studies, using more variable genetic markers are needed to support the current data, as molecular markers could reveal genetic differences that remained undetected in the present work.

Acknowledgements. This research was supported by the MAST 3 programme of the European Commission under contract number MAS3-CT95-0042 (AMBIOS). K. Johannesson and 3 anonymous referees helped to improve the manuscript H.D.W. holds an IWT scholarship.

Appendix 1. Littorina striata. Allele frequencies, observed $\left(H_{\mathrm{obs}}\right)$ and expected $\left(H_{\text {exp }}\right)$ heterozygosity levels, chi-squared $\left(p-\chi^{2}\right)$ and exact probabilities ( $p$-ext) for deviation from Hardy-Weinberg equilibria. na: test statistic non-applicable, due to (1) monomorphic loci or (2) quasi monomorphic loci (i.e. 2 alleles are present, but one is represented only once)

\begin{tabular}{|c|c|c|c|c|c|c|c|c|c|}
\hline Locus & & 1 & 2 & 3 & 4 & 5 & 6 & 7 & 8 \\
\hline \multicolumn{10}{|l|}{1992} \\
\hline \multirow[t]{10}{*}{ GPI } & $\begin{array}{l}(\mathrm{N}) \\
\mathrm{A}\end{array}$ & $\begin{array}{c}40 \\
0.013\end{array}$ & $\begin{array}{c}49 \\
0.000\end{array}$ & $\begin{array}{c}44 \\
0.011\end{array}$ & $\begin{array}{c}61 \\
0.016\end{array}$ & $\begin{array}{c}37 \\
0.014\end{array}$ & $\begin{array}{c}39 \\
0.013\end{array}$ & $\begin{array}{c}49 \\
0.020\end{array}$ & $\begin{array}{c}92 \\
0.005\end{array}$ \\
\hline & $\mathrm{B}$ & 0.325 & 0.276 & 0.307 & 0.369 & 0.365 & 0.256 & 0.276 & 0.277 \\
\hline & C & 0.013 & 0.020 & 0.045 & 0.033 & 0.000 & 0.000 & 0.051 & 0.033 \\
\hline & D & 0.600 & 0.643 & 0.614 & 0.533 & 0.554 & 0.718 & 0.612 & 0.620 \\
\hline & $E$ & 0.000 & 0.000 & 0.000 & 0.016 & 0.000 & 0.000 & 0.000 & 0.016 \\
\hline & F & 0.050 & 0.061 & 0.023 & 0.033 & 0.068 & 0.013 & 0.041 & 0.049 \\
\hline & $H_{\text {obs }}$ & 0.475 & 0.571 & 0.432 & 0.492 & 0.568 & 0.359 & 0.531 & 0.500 \\
\hline & $H_{\exp }$ & 0.532 & 0.507 & 0.527 & 0.577 & 0.555 & 0.418 & 0.545 & 0.536 \\
\hline & $p-\chi^{2}$ & 0.148 & 0.665 & 0.179 & 0.027 & 0.405 & 0.681 & 0.645 & 0.424 \\
\hline & $p$-ext & 0.755 & 0.795 & 0.178 & 0.013 & 0.412 & 0.679 & 0.657 & 0.252 \\
\hline \multirow[t]{9}{*}{ MPI } & $(\mathrm{N})$ & 41 & 36 & 44 & 47 & 37 & 40 & 38 & 90 \\
\hline & A & 0.000 & 0.000 & 0.000 & 0.000 & 0.000 & 0.000 & 0.000 & 0.000 \\
\hline & B & 0.049 & 0.014 & 0.114 & 0.032 & 0.162 & 0.138 & 0.079 & 0.133 \\
\hline & C & 0.951 & 0.986 & 0.886 & 0.968 & 0.838 & 0.863 & 0.912 & 0.867 \\
\hline & $\mathrm{D}$ & 0.000 & 0.000 & 0.000 & 0.000 & 0.000 & 0.000 & 0.000 & 0.000 \\
\hline & $H_{\text {obs }}$ & 0.098 & 0.028 & 0.136 & 0.064 & 0.216 & 0.225 & 0.158 & 0.244 \\
\hline & $H_{\exp }$ & 0.093 & 0.027 & 0.201 & 0.062 & 0.272 & 0.237 & 0.145 & 0.231 \\
\hline & $p-\chi^{2}$ & 1.000 & 1.000 & 0.079 & 1.000 & 0.237 & 1.000 & 1.000 & 0.696 \\
\hline & $p$-ext & 1.000 & na & 0.075 & 1.000 & 0.215 & 0.548 & 1.000 & 1.000 \\
\hline \multirow[t]{9}{*}{ PGD } & $(\mathrm{N})$ & 41 & 49 & 51 & 58 & 39 & 39 & 41 & 90 \\
\hline & A & 0.000 & 0.000 & 0.000 & 0.000 & 0.000 & 0.000 & 0.000 & 0.006 \\
\hline & $B$ & 0.976 & 0.969 & 0.980 & 0.991 & 0.936 & 0.923 & 0.988 & 0.965 \\
\hline & $C$ & 0.024 & 0.031 & 0.020 & 0.009 & 0.064 & 0.077 & 0.012 & 0.028 \\
\hline & $\mathrm{D}$ & 0.000 & 0.000 & 0.000 & 0.000 & 0.000 & 0.000 & 0.000 & 0.011 \\
\hline & $H_{\text {obs }}$ & 0.049 & 0.061 & 0.039 & 0.017 & 0.128 & 0.103 & 0.024 & 0.089 \\
\hline & $H_{\exp }$ & 0.048 & 0.059 & 0.038 & 0.017 & 0.120 & 0.142 & 0.024 & 0.086 \\
\hline & $\mathrm{p}-\chi^{2}$ & 1.000 & 1.000 & 1.000 & 1.000 & 1.000 & 0.194 & 1.000 & 1.000 \\
\hline & $p$-ext & 1.000 & 1.000 & 1.000 & na & 1.000 & 0.187 & na & 1.000 \\
\hline \multirow[t]{7}{*}{$\mathrm{MDH}$} & $(\mathrm{N})$ & 41 & 50 & 52 & 57 & 39 & 37 & 48 & 90 \\
\hline & A & 0.000 & 0.000 & 0.000 & 0.009 & 0.000 & 0.000 & 0.000 & 0.017 \\
\hline & B & 1.000 & 1.000 & 1.000 & 0.991 & 1.000 & 1.000 & 1.000 & 0.983 \\
\hline & $H_{\text {obs }}$ & 0.000 & 0.000 & 0.000 & 0.018 & 0.000 & 0.000 & 0.000 & 0.033 \\
\hline & $H_{\exp }$ & 0.000 & 0.000 & 0.000 & 0.017 & 0.000 & 0.000 & 0.000 & 0.033 \\
\hline & $p-\chi^{2}$ & na & na & na & 1.000 & na & nà & na & 1.000 \\
\hline & p-ext & na & na & na & na & na & na & na & 1.000 \\
\hline \multicolumn{10}{|l|}{1993} \\
\hline \multirow[t]{11}{*}{ GPI } & $(\mathrm{N})$ & 38 & 36 & 39 & 26 & 38 & 38 & 40 & 39 \\
\hline & A & 0.026 & 0.000 & 0.051 & 0.000 & 0.039 & 0.000 & 0.000 & 0.000 \\
\hline & B & 0.316 & 0.222 & 0.282 & 0.442 & 0.197 & 0.237 & 0.237 & 0.218 \\
\hline & C & 0.053 & 0.014 & 0.013 & 0.000 & 0.026 & 0.013 & 0.000 & 0.013 \\
\hline & $D$ & 0.579 & 0.736 & 0.641 & 0.538 & 0.684 & 0.724 & 0.724 & 0.712 \\
\hline & $E$ & 0.000 & 0.000 & 0.000 & 0.000 & 0.013 & 0.000 & 0.000 & 0.000 \\
\hline & $\mathrm{F}$ & 0.026 & 0.028 & 0.013 & 0.019 & 0.039 & 0.026 & 0.026 & 0.050 \\
\hline & $H_{\mathrm{obs}}$ & 0.526 & 0.417 & 0.462 & 0.346 & 0.447 & 0.447 & 0.525 & 0.436 \\
\hline & $H_{\exp }$ & 0.561 & 0.408 & 0.507 & 0.514 & 0.489 & 0.419 & 0.433 & 0.417 \\
\hline & $\mathrm{p}-\chi^{2}$ & 0.148 & 1.000 & 0.519 & 0.082 & 0.326 & 0.903 & 0.270 & 1.000 \\
\hline & p-ext & 0.105 & 1.000 & 0.582 & 0.070 & 0.438 & 1.000 & 0.369 & 1.000 \\
\hline
\end{tabular}


Appendix 1 (continued)

\begin{tabular}{|c|c|c|c|c|c|c|c|c|c|}
\hline \multicolumn{2}{|l|}{ Locus } & 1 & 2 & 3 & 4 & 5 & 6 & 7 & 8 \\
\hline \multicolumn{10}{|c|}{1993 (continued) } \\
\hline \multirow[t]{9}{*}{ MPI } & $(\mathrm{N})$ & 38 & 36 & 39 & 28 & 31 & 37 & 39 & 37 \\
\hline & A & 0.000 & 0.000 & 0.000 & 0.000 & 0.000 & 0.000 & 0.000 & 0.000 \\
\hline & B & 0.066 & 0.125 & 0.064 & 0.143 & 0.048 & 0.135 & 0.115 & 0.149 \\
\hline & $\mathrm{C}$ & 0.934 & 0.875 & 0.936 & 0.857 & 0.952 & 0.865 & 0.885 & 0.851 \\
\hline & D & 0.000 & 0.000 & 0.000 & 0.000 & 0.000 & 0.000 & 0.000 & 0.000 \\
\hline & $H_{\mathrm{obs}}$ & 0.079 & 0.194 & 0.128 & 0.214 & 0.097 & 0.270 & 0.231 & 0.243 \\
\hline & $H_{\text {exp }}$ & 0.123 & 0.219 & 0.120 & 0.245 & 0.092 & 0.234 & 0.204 & 0.253 \\
\hline & $p \cdot \chi^{2}$ & 0.109 & 1.000 & 1.000 & 1.000 & 1.000 & 0.610 & 0.642 & 1.000 \\
\hline & p-ext & 0.130 & 0.434 & 1.000 & 0.440 & 1.000 & 1.000 & 1.000 & 1.000 \\
\hline \multirow[t]{9}{*}{ PGD } & $(\mathrm{N})$ & 34 & 35 & 40 & 25 & 34 & 37 & 37 & 36 \\
\hline & A & 0.000 & 0.000 & 0.000 & 0.000 & 0.000 & 0.000 & 0.000 & 0.000 \\
\hline & $\mathrm{B}$ & 1.000 & 0.957 & 1.000 & 1.000 & 0.956 & 0.986 & 0.946 & 0.917 \\
\hline & $\mathrm{C}$ & 0.000 & 0.043 & 0.000 & 0.000 & 0.015 & 0.014 & 0.054 & 0.083 \\
\hline & $\mathrm{D}$ & 0.000 & 0.000 & 0.000 & 0.000 & 0.029 & 0.000 & 0.000 & 0.000 \\
\hline & $H_{\mathrm{obs}}$ & 0.000 & 0.086 & 0.000 & 0.000 & 0.029 & 0.027 & 0.108 & 0.111 \\
\hline & $H_{\exp }$ & 0.000 & 0.082 & 0.000 & 0.000 & 0.085 & 0.027 & 0.102 & 0.153 \\
\hline & $p-\chi^{2}$ & na & 1.000 & na & na & 0.013 & 1.000 & 1.000 & 0.199 \\
\hline & $p$-ext & na & 1.000 & na & na & 0.014 & na & na & 0.202 \\
\hline \multirow[t]{7}{*}{$\mathrm{MDH}$} & $(\mathrm{N})$ & 34 & 35 & 30 & 25 & 37 & 38 & 37 & 38 \\
\hline & A & 0.000 & 0.014 & 0.000 & 0.000 & 0.014 & 0.000 & 0.000 & 0.000 \\
\hline & B & 1.000 & 0.986 & 1.000 & 1.000 & 0.986 & 1.000 & 1.000 & 1.000 \\
\hline & $H_{\mathrm{obs}}$ & 0.000 & 0.029 & 0.000 & 0.000 & 0.027 & 0.000 & 0.000 & 0.000 \\
\hline & $H_{\text {exp }}$ & 0.000 & 0.028 & 0.000 & 0.000 & 0.027 & 0.000 & 0.000 & 0.000 \\
\hline & $p-\chi^{2}$ & na & 1.000 & na & na & 1.000 & na & na & na \\
\hline & p-ext & na & na & na & na & na & na & na & na \\
\hline \multicolumn{10}{|l|}{1994} \\
\hline \multirow[t]{11}{*}{ GPI } & (N) & 40 & 35 & 33 & 38 & 38 & 40 & 39 & 40 \\
\hline & A & 0.013 & 0.000 & 0.000 & 0.000 & 0.000 & 0.013 & 0.038 & 0.000 \\
\hline & B & 0.250 & 0.343 & 0.303 & 0.408 & 0.408 & 0.275 & 0.256 & 0.387 \\
\hline & $\mathrm{C}$ & 0.013 & 0.014 & 0.015 & 0.026 & 0.013 & 0.000 & 0.026 & 0.025 \\
\hline & D & 0.675 & 0.600 & 0.652 & 0.513 & 0.526 & 0.663 & 0.641 & 0.575 \\
\hline & E & 0.000 & 0.000 & 0.000 & 0.039 & 0.000 & 0.000 & 0.013 & 0.000 \\
\hline & F & 0.050 & 0.043 & 0.030 & 0.013 & 0.053 & 0.050 & 0.026 & 0.013 \\
\hline & $H_{\mathrm{obs}}$ & 0.450 & 0.543 & 0.455 & 0.500 & 0.447 & 0.450 & 0.385 & 0.525 \\
\hline & $H_{\exp }$ & 0.479 & 0.520 & 0.483 & 0.568 & 0.554 & 0.483 & 0.520 & 0.518 \\
\hline & $p-\chi^{2}$ & 0.837 & 1.000 & 0.677 & 0.001 & 0.364 & 0.394 & 0.207 & 0.492 \\
\hline & p-ext & 0.763 & 1.000 & 0.811 & 0.012 & 0.331 & 0.343 & 0.083 & 0.607 \\
\hline \multirow[t]{9}{*}{ MPI } & $(\mathrm{N})$ & 39 & 35 & 38 & 38 & 40 & 40 & 40 & 40 \\
\hline & A & 0.000 & 0.014 & 0.000 & 0.000 & 0.000 & 0.000 & 0.000 & 0.000 \\
\hline & B & 0.115 & 0.129 & 0.105 & 0.053 & 0.112 & 0.138 & 0.063 & 0.125 \\
\hline & $\mathrm{C}$ & 0.885 & 0.843 & 0.895 & 0.947 & 0.887 & 0.863 & 0.938 & 0.875 \\
\hline & D & 0.000 & 0.014 & 0.000 & 0.000 & 0.000 & 0.000 & 0.000 & 0.000 \\
\hline & $H_{\mathrm{obs}}$ & 0.231 & 0.286 & 0.211 & 0.105 & 0.225 & 0.275 & 0.075 & 0.250 \\
\hline & $H_{\exp }$ & 0.204 & 0.273 & 0.188 & 0.100 & 0.200 & 0.237 & 0.117 & 0.219 \\
\hline & $\mathrm{p}-\chi^{2}$ & 0.635 & 0.121 & 1.000 & 1.000 & 0.688 & 0.609 & 0.099 & 0.611 \\
\hline & p-ext & 1.000 & 0.321 & 1.000 & 1.000 & 1.000 & 1.000 & 0.124 & 1.000 \\
\hline \multirow[t]{9}{*}{ PGD } & $(\mathrm{N})$ & 37 & 33 & 39 & 38 & 39 & 40 & 40 & 40 \\
\hline & A & 0.000 & 0.000 & 0.000 & 0.000 & 0.013 & 0.000 & 0.000 & 0.000 \\
\hline & B & 0.973 & 0.970 & 0.974 & 0.974 & 0.962 & 0.962 & 0.988 & 0.962 \\
\hline & C & 0.000 & 0.030 & 0.000 & 0.026 & 0.000 & 0.038 & 0.000 & 0.000 \\
\hline & $\mathrm{D}$ & 0.027 & 0.000 & 0.026 & 0.000 & 0.026 & 0.000 & 0.013 & 0.038 \\
\hline & $H_{\text {obs }}$ & 0.054 & 0.061 & 0.051 & 0.053 & 0.077 & 0.075 & 0.025 & 0.075 \\
\hline & $H_{\text {exp }}$ & 0.053 & 0.059 & 0.050 & 0.051 & 0.075 & 0.072 & 0.025 & 0.072 \\
\hline & $p-\chi^{2}$ & 1.000 & 1.000 & 1.000 & 1.000 & 1.000 & 1.000 & 1.000 & 1.000 \\
\hline & p-ext & 1.000 & 1.000 & 1.000 & 1.000 & 1.000 & 1.000 & na & 1.000 \\
\hline \multirow[t]{7}{*}{$\mathrm{MDH}$} & $(\mathrm{N})$ & 36 & 39 & 40 & 40 & 40 & 40 & 40 & 40 \\
\hline & A & 0.000 & 0.000 & 0.000 & 0.025 & 0.000 & 0.000 & 0.000 & 0.013 \\
\hline & B & 1.000 & 1.000 & 1.000 & 0.975 & 1.000 & 1.000 & 1.000 & 0.987 \\
\hline & $H_{\mathrm{obs}}$ & 0.000 & 0.000 & 0.000 & 0.050 & 0.000 & 0.000 & 0.000 & 0.025 \\
\hline & $H_{\exp }$ & 0.000 & 0.000 & 0.000 & 0.049 & 0.000 & 0.000 & 0.000 & 0.025 \\
\hline & $p-\chi^{2}$ & na & na & na & 1.000 & na & na & na & 1.000 \\
\hline & p-ext & na & na & na & 1.000 & na & na & na & na \\
\hline
\end{tabular}




\section{LITERATURE CITED}

Backeljau T, Warmoes T (1992) The phylogenetic relationships of ten Atiantic Littorinids assessed by allozyme electrophoresis. In: Grahame J, Mill P, Reid D (eds) Proceed. ings of the 3rd International Symposium on Littorinid Biology. The Malacological Society of London, London, p $9-24$

Benzie JAH, Williams TS (1996) Limitations in the genetic variation of hatchery produced batches of the giant clam, Tridacna gigas. Aquaculture 139:225-241

Boulding EG, Van Alstyne KL (1993) Mechanisms of differential survival and growth of two species of Littorina on wave-exposed and on protected shores. J Exp Mar Biol Ecol 169:139-166

Britton JC (1995) The relationship between position on shore and shell ornamentation in two size-dependent morphotypes of Littorina striata, with an estimate of evaporative water loss in these morphotypes and in Melarhaphe neritoides. Hydrobiologia 309:129-142

Brown LD (1991) Genetic variation and population structure in the Blacklip abalone. Haliotis rubra. Aust J Mar Freshwat Res 42:77-90

Chapman MG (1994) Small-scale patterns of distribution and size-structure of the intertidal littorinid Littorina unifasciata (Gastropoda: Littorinidae) in New South Wales. Aust $J$ Mar Freshwat Res 45:635-652

Crisp DJ (1978) Genetic consequences of different reproductive strategies in marine invertebrates. In: Battaglia $B_{\text {, }}$ Beardmore JA (eds) Marine organisms, ecology and evolution. Plenum Press, New York, p 257-269

Crothers JH (1981) Shell-shape variation in Faroese dogwhelks (Nucella lapillus (L.)). Biol J Linn Soc 15:327-337

Crothers JH (1992) Shell size and shape variation in Littorina Littorea (L.) from west Somerset. In: Grahame J, Mill P, Reid D (eds) Proceedings of the 3rd International Symposium on Littorinid Biology. The Malacological Society of London, London, p 91-97

Dayan NS, Dillon RT Jr (1995) Florida as a biogeographic boundary: evidence from population genetics of Littorina irrorata. Nautilus 108:49-54

De Wolf $\mathrm{H}$, Backeljau T, Jordaens K, Medeiros R, Verdyck P, Verhagen R (1995) A comparison of gene flow estimates based on private allele frequencies. Belg $\mathrm{J}$ Zool 125: $101-107$

De Wolf H, Medeiros R, Backeljau T, Verhagen R (1997) Microgeographical shell variation in Littorina striata, a planktonic developing periwinkle. Mar Biol 129:331-342

Dunker W (1853) Index molluscorum, quae in itinere ad Guineam inferiorem collegit Georgius Tams Med. Dr. Noviates Conchologicae Suppl 2:1-74

Ford MJ, Mitton JB (1993) Population structure of the pink barnacle Tetraclita squamosa rubescens, along the California coast. Mol Mar Biol Biotech 2:147-153

Frid CLJ, Fordham E (1994) The morphology of the sub-littoral gastropod Gibulla cineraria (L.) along a gradient of wave action. Ophelia 40:135-146

Gaffney PM, Scott TM, Koehn RK, Diehl WJ (1990) Interrelationships of heterozygosity, growth rate and heterozygote deficiencies in the coot clam, Mulinia lateralis. Genetics 124:687-699

Grant WS, Utter FM (1988) Genetic heterogeneity on different geographic scales in Nucella lamellosa (Prosobranchia, Thaididae). Malacologia 28:275-287

Guo SW, Thompson EA (1992) Performing the exact test of Hardy-Weinberg proportion for multiple alleles. Biometrics 48:361-372
Harris H, Hopkinson DA (1976) Handbook of enzyme electrophoresis in human genetics. Elsevier, Amsterdam

Hull SL, Grahame J, Mill PJ (1996) Morphological divergence and evidence for reproductive isolation in Littorina saxatilis (Olivi) in Northeast England. J Mollusc Stud 62: $89-99$

Janson K (1985a) Genetic variation in three Caribbean periwinkles, Littorina angustior, L. lineolineata and L. ziczaC (Gastropoda:Prosobranchia). Bull Mar Sci 37:871-879

Janson K (1985b) Genetic and morphologic variation within and between populations of Littorina angulifera from Florida. Ophelia 24:125-134

Johannesson B (1996) Polymorphism and population structure in the intertidal snail Littorina saxatilis. PhD dissertation, University of Göteborg

Johannesson B, Johannesson K (1996) Population differences in behaviour and morphology in the snail Littorina saxatilis: phenotypic plasticity or genetic differentiation? J Zool (London) 240:475-493

Johannesson K (1992) Genetic variability and large scale differentiation in two species of littorinid gastropods with planktotrophic development, Littorina littorea (L.) and Melarhaphe (Littorina) neritoides (L.). Biol J Linn Soc 47 : 285-299

Johannesson K, Johannesson B (1990) Genetic variation within Littorina saxatilis (Olivi) and Littorina neglecta Bean: is $L$. neglecta a good species? Hydrobiologia 193: $89-97$

Johannesson K, Johannesson B, Rolan-Alvarez E (1993) Morphological differentiation and genetic cohesiveness over a micro-environmental gradient in the marine snail Littorina saxatilis. Evolution 47:1770-1787

Johannesson K, Rolan-Alvarez E, Ekendahl A (1995) Incipient reproductive isolation between two sympatric morphs of the intertidal snail Littorina saxatilis. Evolution 49: $1180-1190$

Johannesson K, Tatarenkov A (1997) Allozyme variation in a snail (Littorina saxatilis) - deconfounding the effects of microhabitat and gene flow. Evolution 51:402-409

Johnson MS, Black R (1996) Geographic cohesiveness versus associations with habitat: subdivision of Bembicium vittatum Philippi (Gastropoda: Littorinidae) in the Houtman Abrolhos [slands. Biol J Linn Soc 58:57-74

Karakousis Y, Spandou E. Sophronidis K, Triantaphyllidis C (1993) Morphological and allozymic variation in populations of Mytilus galloprovincialis from the Aegean Sea. J Mollusc Stud 59:165-173

Kartavtsev YP, Zaslavskaya NI (1983) Allozyme polymorphism in a population of the common mussel Mytilus edulis L. (Mytilidae) from the Sea of Japan. Mar Biol Lett $4: 163-172$

Knight AJ, Hughes RN, Ward RD (1987) A striking example of the founder effect in the mollusc Littorina saxatilis. Biol $J$ Linn Soc 32:417-426

Koehn RK, Gaffney PM (1984) Genetic heterozygosity and growth rate in Mytilus edulis. Mar Biol 82:1-7

Lewis PO (1992) GENESTAT-PC $\vee 3.31$ computer package manual. North Carolina State University, Raleigh

Macaranas JM, Ablan CA, Pante MJR, Benzie JAH, Williams ST (1992) Genetic structure of giant clam (Tridacna derasa) populations from the reefs in the Indo-Pacific. Mar Biol 113:231-238

Maestro EV, Chow V, Hedgecock D (1982) Littorina scutulata and Littorina plena; sibling species confirmed by electrophoresis. Veliger 24:239-246

McQuaid CD (1996) Biology of the Gastropod family Littorinidae. II. Role in the ecology of intertidal and shallow 
marine ecosystems. Oceanogr Mar Biol Rev 34:263-302

Morton B (1990) The intertidal ecology of Ilheu de Vila Franca-a drowned volcanic crater in the Azores. Açoreana Suppl:3-20

Nei M (1973) Analysis of gene diversity in subdivided populations. Proc Natl Acad Sci USA 70:3321-3323

Nei M (1977) F-statistics and analysis of gene diversity in subdivided populations. Annu Hum Genet 41:225-233

Palumbi SR (1994) Genetic divergence reproductive isolation, and marine speciation. Annu Rev Ecol Syst 25: 547-572

Parsons KE, Ward RD (1994) Electrophoretic and morphometric examination of Austrochlea constricta (Gastropoda: Trochidae): a species complex. Aust J Mar Freshwat Res 45:1065-1085

Raymond M, Rousset F (1995) GENEPOP v 1.1: population genetics software for exact tests and ecumenicism. J Hered 86:248-249

Reid DG (1996) Systematics and evolution of Littorina. The Ray Society, London

Reimer O, Tendengren M (1996) Phenotypical improvement of morphological defences in the mussel Mytilus edulis induced by exposure to the predator Asterias rubens. Oikos 75:383-390

Rice WR (1989) Analyzing tables of statistical tests. Evolution 43:223-225

Roff DA, Bentzen P (1989) The statistical analysis of mitochondrial DNA polymorphisms: chi-squared and the problem of small samples. Mol Biol Evol 6:539-545

Rohlf FJ (1993) NTSYS-pc: numerical taxonomy and multivariate analysis system, v 1.80. Applied Biostatistics Inc, Setauket, NY

Rolán-Alvarez E, Rolán E, Johannesson K (1996) Differentiation in radular and embryonic characters and further comments on gene flow, between two sympatric morphs of Littorina saxatilis (Olivi). Ophelia 45:1-15

Rolán-Alvarez E, Zapata C, Alvarez G (1995) Distinct genetic subdivision in sympatric and sibling species of the genus Littorina (Gastropoda: Littorinidae). Heredity 74:1-9

Rosewater J (1981) The family Littorinidae in the Indo Pacific. Part I the subfamily littorininae. Indo Pacif Mollusca 2: 417-506

Scheltema RS (1971) Larval dispersal as a mean of genetic exchange between geographically separated populations of shallow-water benthic marine gastropods. Biol Bull Mar Biol Lab Woods Hole 140:284-322

Seeley RH (1986) Intense natural selection caused a rapid

Editorial responsibility: Otto Kinne (Editor),

Oldendorf/Luhe, Germany morphological transition in a living marine snail. Proc Nat Acad Sci USA 83:6897-6901

Slatkin M (1985a) Rare alleles as indicator of gene flow. Evolution 39:53-56

Slatkin M (1985b) Gene flow in natural populations. Annu Rev Ecol Syst 16:393-430

Slatkin M, Barton NH (1989) A comparison of three indirect methods for estimating average levels of gene flow. Evolution 43:1349-1368

Stiven AE (1992) Genetic structure in a population of ribbed mussel Geukensia demissa (Dillwyn) in a North Carolina salt marsh tidal gradient. J Exp Mar Biol Ecol 164:31-44

Struhsaker JW (1968) Selection mechanisms with intraspecific shell variation in Littorina picta (Prosobranchia: Mesogastropoda). Evolution 22:459-480

Swofford DL, Selander RB (1989) BIOSYS. A computer program for the analysis of allelic variation in population genetics and biochemical systematics. Release 1.7. University of Ulinois, Urbana

Tatarenkov A, Johannesson K (1994) Habitat related allozyme variation on a microgeographic scale in the marine snail Littorina mariae (Prosobranchia, Littorinacea). Biol J Linn Soc 53:105-125

Vedel G, Depledge $M$ (1995) Temperature tolerance and selected trace metal concentrations in some Azorean gas tropod molluscs. Açoreana Suppl:113-124

Ward RD (1990) Biochemical genetic variation in the genus Littorina (Prosobranchia: Mollusca). Hydrobiologia 193: $53-69$

Weinkauff HC (1882) Die Gattung Littorina. Angefangen von Dr. Kuster, durchgesehen, ergänzt und vollendet von $\mathrm{HC}$ Weinkauff. In: Kuster HC, Kobelt W, Weinkauff HC (eds) Systematisches Conchylien-Cabinet von Martini und Chemnitz. Bauer and Raspe, Nurnberg

Wright S (1965) The interpretation of population structure by F-statistics with special regard to systems of mating. Evolution 19:395-420

Wright S (1978) Evolution and genetics in populations, Vol 4 Variability within and among natural populations. University of Chicago Press, Chicago

Zaykin VD, Pudovkin IA (1993) Two programs to estimate significance of chi-squared values using pseudo-probability tests. J Hered 84:152

Zouros E, Pogson GH (1994) The present status of the relationship between heterozygosity and heterosis. In: Beaumont AR (ed) Genetics and evolution of aquatic organisms. Chapman and Hall, London, p 135-146

Submitted: August 8, 1997; Accepted: December 10, 1997 Proofs received from author(s): February 16, 1998 